\title{
Heat Waves Are a Major Threat to Turbid Coral Reefs in Brazil
}

OPEN ACCESS

Edited by:

Hajime Kayanne,

The University of Tokyo, Japan

Reviewed by:

Robert Van Woesik,

Florida Institute of Technology,

United States

Aldo Cróquer,

Simón Bolivar University, Venezuela

*Correspondence:

Raquel S. Peixoto

raquelpeixoto@micro.ufr.j.br

${ }^{\dagger}$ These authors have contributed equally to this work

Specialty section: This article was submitted to

Coral Reef Research,

a section of the journal

Frontiers in Marine Science

Received: 27 November 2019

Accepted: 06 March 2020

Published: 30 March 2020

Citation:

Duarte GAS, Villela HDM,

Deocleciano M, Silva D, Barno A,

Cardoso PM, Vilela CLS, Rosado P,

Messias CSMA, Chacon MA,

Santoro EP, Olmedo DB, Szpilman M,

Rocha $L A$, Sweet $M$ and Peixoto RS

(2020) Heat Waves Are a Major

Threat to Turbid Coral Reefs in Brazil.

Front. Mar. Sci. 7:179.

doi: 10.3389/fmars.2020.00179
Gustavo A. S. Duarte ${ }^{1,2+}$, Helena D. M. Villela ${ }^{1 \dagger}$, Matheus Deocleciano $^{3}$, Denise Silva $^{1}$ Adam Barno', Pedro M. Cardoso', Caren L. S. Vilela1, Phillipe Rosado1, Camila S. M. A. Messias ${ }^{1}$, Maria Alejandra Chacon ${ }^{1}$, Erika P. Santoro ${ }^{1}$, Daniele B. Olmedo' ${ }^{1}$, Marcelo Szpilman ${ }^{2,3}$, Luiz A. Rocha ${ }^{4}$, Michael Sweet ${ }^{5}$ and Raquel S. Peixoto ${ }^{1,2,6 *}$

${ }^{1}$ Institute of Microbiology, Federal University of Rio de Janeiro, Rio de Janeiro, Brazil, ${ }^{2}$ Rio de Janeiro Marine Aquarium Research Center, Rio de Janeiro, Brazil, ${ }^{3}$ Rio de Janeiro Marine Aquarium, Rio de Janeiro, Brazil, ${ }^{4}$ California Academy of Sciences, San Francisco, CA, United States, ${ }^{5}$ Aquatic Research Facility, Environmental Sustainability Research Centre, University of Derby, Derby, United Kingdom, ${ }^{6}$ Genome Center, University of California, Davis, Davis, CA, United States

Coral reefs are threatened by climate change on a global scale with thermal stress events and mass coral bleaching being widely reported. The reefs off the east coast of Brazil (and other turbid areas) have, however, historically escaped such thermal stress events, with relatively low levels of background coral mortality (5-10\%). This has recently changed. Here we show that, in 2019, degree heating weeks (DHW) of 19.65 coincided with catastrophic declines in coral cover, especially in the major reef building hydrocoral Millepora alcicornis. The decline was due to bleaching associated with exposure to high temperature stress culminating in DHW values exceeding 15 for a period of 50 days. At two independent sites, surveys showed upwards of $83.5 \pm 9.0$ and $89.1 \pm 3.9 \%$ mortality, and a third site showed relatively lower (albeit still high) mortality rates of $43.3 \pm 12.0 \%$. The mass die-off in 2019 is unprecedented in the South Atlantic reefs and coincides with increased heating events.

Keywords: coral mortality, Millepora alcicornis, mass bleaching, turbid reefs, coral reefs, global warming

\section{INTRODUCTION}

A large proportion of all marine life is supported by coral reefs (Paulay, 1997). Such ecosystems also benefit, either directly or indirectly, approximately 500 million people around the globe (Burke et al., 2011). These ecosystems, however, are under direct threat, with climate change being identified as the major force affecting coral health on a global scale (Hughes et al., 2017). The impacts of climate change on coral reefs have been widely reported (National Academies of Sciences and Medicine, 2019), and it is now known that corals in different regions differ in their susceptibility to this global threat (Hughes et al., 2018; Banha et al., 2019; Teixeira et al., 2019).

A number of reef "oases" have been identified at sites that positively deviate from regional means (Guest et al., 2018). In these sites, several physical and biological mechanisms allow corals to survive and even thrive despite the global increases in sea surface temperatures (Côté and Darling, 2010). For instance, nearshore reefs seem to be more resistant to coral bleaching during thermal stress events (Morgan et al., 2016, 2017), potentially due to greater turbidity that reduces solar irradiance (De'ath et al., 2012; Cacciapaglia and van Woesik, 2015). In addition, turbid reefs have 
higher loads of suspended particulate matter, which can favor coral heterotrophic feeding in some coral species (Anthony and Fabricius, 2000) and, therefore, could contribute to higher resistance and recovery after temperature anomalies.

South Atlantic reefs appear to be one of those refuges, as they have escaped multiple thermal stress events which have plagued the Indo-Pacific and Caribbean. Despite massive coral loss seen throughout the world, coral reefs in the South Atlantic have remained relatively stable (Perry et al., 2013; Banha et al., 2019; Teixeira et al., 2019). The relatively high turbidity present throughout most of the year along the Brazilian coast (Teixeira et al., 2019) provides corals with potential refuge against the rising sea surface temperature (SST). For example, during the Third Global Bleaching Event between 2014 and 2017, Brazilian reefs only suffered a loss of $3 \%$ due to bleaching and disease, much lower than the majority of other sites (Miranda et al., 2013; Teixeira et al., 2019).

Here, however, we documented the first mass die-off recorded in South Atlantic reefs during a record breaking heat wave event (in 2019) across three sites: two reefs within the Abrolhos Bank, consisting of the more pristine Itacolomis Reef Complex (IRC) and the Coroa Vermelha (CV) reef, which is more impacted by local anthropogenic activities (Costa, 2007).

\section{MATERIALS AND METHODS}

\section{Study Region}

Three sites were chosen, in order to characterize the extent and intensity of bleaching during the 2019 heat wave in Brazil. Two of these were within the Itacolomis Reef Complex (IRC, $16^{\circ} 55^{\prime} \mathrm{S}$, $39^{\circ} 03^{\prime \prime} \mathrm{W}$ ) within the Marine Extractive Reserve of Corumbau (MERC). The IRC is the largest reef complex in the MERC $\left(\sim 50 \mathrm{~km}^{2}\right)$, comprised of a dozen reef areas interspersed by canals. We chose two sites separated by $\sim 6 \mathrm{~km}$ to survey in the IRC: Pedra do Silva (PS, $16^{\circ} 53^{\prime} 16^{\prime \prime} \mathrm{S}, 39^{\circ} 05^{\prime} 30^{\prime \prime} \mathrm{W}$ ) and Virada de Fora (VF, $\left.16^{\circ} 54^{\prime} 02^{\prime \prime} \mathrm{S}, 39^{\circ} 02^{\prime} 28^{\prime \prime} \mathrm{W}\right)$. The third location surveyed was Coroa Vermelha (CV, $\left.16^{\circ} 20^{\prime} 41^{\prime \prime} \mathrm{S}, 38^{\circ} 58^{\prime} 25^{\prime \prime} \mathrm{W}\right)$, located in Santa Cruz de Cabralia which is $\sim 3 \mathrm{~km}$ offshore outside the marine protected area and exposed to intense fishing (Leão et al., 2008). The CV and IRC are $70 \mathrm{~km}$ apart north to south (Figure 1, map). All surveys were conducted between June 25th, 2019 and July 5th, 2019.

\section{Sampling Design and Field Measurements}

A slightly modified belt transect method (Hill and Wilkinson, 2004) was used to assess the percentage of bleached corals and hydrocorals as well as to estimate the mortality caused by the 2019 heat wave. Twenty-meter long transects were used to suit the structure of the reefs. The video transects were taken with a $4 \mathrm{~K}$ underwater camera recording at $40 \mathrm{~cm}$ above the reef structure, following the tape measure through surface roughness, at $10 \mathrm{~m} / \mathrm{min}$. Video transects were performed in each of the three sites: 10 in VF reef, 11 in PS reef and 9 in CV reefs. All transects were between 4 to $8 \mathrm{~m}$ depth, and their sites were randomly chosen representing both reef crest and wall.
Each transect was divided into non-overlapping frames. Benthic organisms were estimated by relative cover through identification to lowest possible taxonomic level using $\sim 2,000$ randomly distributed points per transect with the Coral Point Count Excel Extensions Software (Kohler and Gill, 2006). Corals and hydrocorals were classified as "healthy" ( $\mathrm{R}$, without bleaching signal), "partially bleached" ( $\mathrm{PB}$, when pigmentation was $\geq 50 \%$ of the intensity of resistant colonies) and "severely bleached" (B, when pigmentation was $<50 \%)$. Corals with recent secondary algae colonization on exposed skeleton and/or tissue loss above $90 \%$ were labeled as recently dead corals (RDC). The final category included colonies where the skeleton was colonized by turf algae, crustose coralline algae or macroalgae for example, and were referred to as "old dead corals" (ODC).

\section{Environmental Variables}

Daily SST and degree heating week values (DHW) were obtained from the Abrolhos reef station using data collected from January 2010 to July 2019 via the NOAA Coral Reef Watch program, using CoralTemp Version 1.0 SST data product, with $5 \mathrm{~km}^{2}$ resolution dataset. DHW is a mass bleaching index and represents the accumulation of the exceeding temperature on the maximum mean SST in a monthly interval (Kayanne, 2017). This index is calculated according to the local temperature average, making regions with different temperatures comparable. Corals exposed to $4.0 \mathrm{DHW}$ usually bleach at a percentage of $30-40 \%$, whereas corals exposed to DHW above 8.0 result in severe bleaching $(>70 \%)$ with subsequent higher rates of coral mortality (Donner et al., 2005; Kayanne, 2017).

The Abrolhos reef station was selected to analyze the weather patterns in the region due to its proximity to the sampling sites. The accumulation of DHW is a measure of thermal stress and has been monitored by NOAA since January $1985^{1}$. One DHW is equal to a week of SSTs that are one degree higher than the warmest monthly mean temperature of the site climatology (Donner et al., 2005). Average DHW values were compared using the non-parametric Kruskal-Wallis test.

Other environmental parameters (temperature, conductivity, $\mathrm{pH}$ and dissolved oxygen) were obtained using a YSI Professional multiparameter probe deployed in the field at the time of the surveys (Yellow Springs Instruments, United States). Nitrate and orthophosphate values were obtained with a portable colorimeter (Hach Portable Colorimeter, model DR900, Hach Co., Loveland, CO, United States). The summary statistics analysis was performed using the Paleontological Statistics Software (PAST) version 3.20.

\section{Data Analysis}

All statistical analyses were conducted with the $\mathrm{R}$ software (Version 3.6.1; R Core Team, 2017). Among sites, we calculated the average $( \pm S E)$ percent coverage of each taxon (see Supplementary Information for all species identified and recorded). We used the Kruskal-Wallis test ( $\mathrm{R}$ package FSA for non-normal data; Ogle et al., 2019) to determine if there were differences in the percent coverage of coral species or in the

\footnotetext{
${ }^{1}$ https://coralreefwatch.noaa.gov/product $/ 5 \mathrm{~km}$
} 


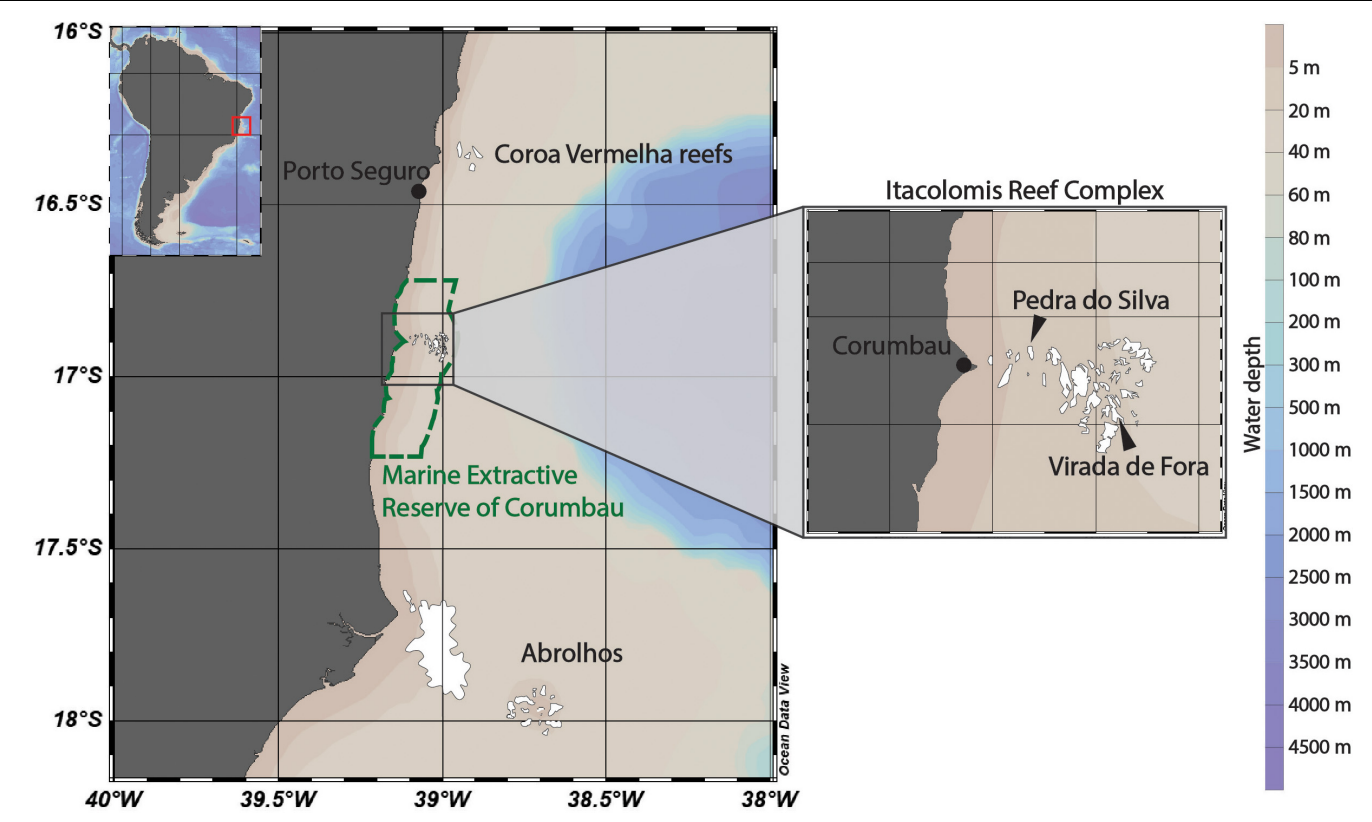

FIGURE 1 | Map of study areas. Samples were collected from the Coroa Vermelha reefs and Pedra do Silva and Virada de Fora reefs within the Itacolomis Reef Complex from June 25, 2019 to July 5, 2019. The Itacolomis Reef Complex is in the protected Marine Extractive Reserve of Corumbau.

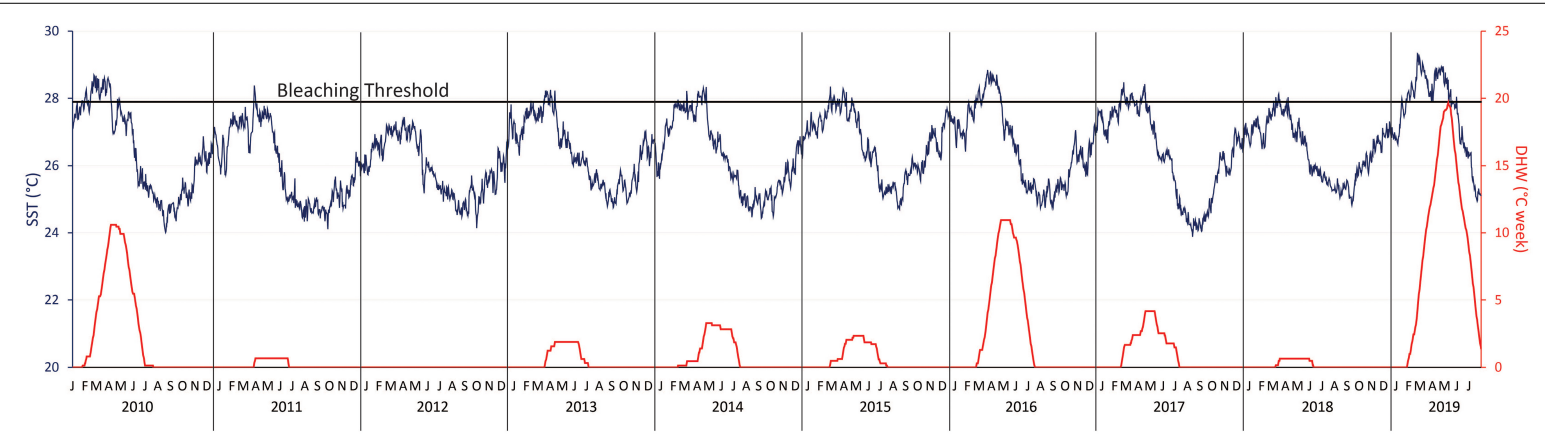

FIGURE 2 | Sea surface temperatures (SST) and degree heating weeks (DHW) in the last decade using daily temperature readings from the Abrolhos reef. The bleaching threshold for the region is $27.9^{\circ} \mathrm{C}$. The year 2019 contained the highest recorded SST and DHW values of the last decade.

TABLE 1 | Summary statistics of physical-chemical parameters from Santa Cruz de Cabralia and Corumbau.

\begin{tabular}{|c|c|c|c|c|c|c|c|}
\hline & Temperature $\left({ }^{\circ} \mathbf{C}\right)$ & Dissolved oxygen (\%) & Salinity (g/L) & Condutivity (uS/cm) & $\mathrm{pH}$ & NO3 (mg/L) & PO4 (mg/L) \\
\hline \multicolumn{8}{|c|}{ Santa Cruz de Cabralia (CV) } \\
\hline Mean & 27.47 & 94.63 & 36.55 & 57.97 & 8.17 & 0.00 & 0.22 \\
\hline Std. error & 0.03 & 1.12 & 0.05 & 0.02 & 0.01 & 0.00 & 0.09 \\
\hline Min & 27.40 & 92.50 & 36.50 & 57.93 & 8.15 & 0.00 & 0.12 \\
\hline Max & 27.50 & 96.30 & 36.60 & 58.00 & 8.19 & 0.01 & 0.40 \\
\hline \multicolumn{8}{|c|}{ Corumbau (PS and VF) } \\
\hline Mean & 27.13 & 98.22 & 36.06 & 56.89 & 8.16 & 0.00 & 0.17 \\
\hline Std. error & 0.07 & 1.35 & 0.22 & 0.22 & 0.02 & 0.00 & 0.06 \\
\hline Min & 26.90 & 93.60 & 35.60 & 56.29 & 8.10 & 0.00 & 0.08 \\
\hline Max & 27.30 & 100.80 & 36.80 & 57.57 & 8.19 & 0.02 & 0.39 \\
\hline
\end{tabular}

health states of colonies of the dominant reef building hydrocoral, M. alcicornis, between and within sites (i.e., apparently healthy colonies, partially bleached, bleached, and recently dead). The richness and diversity among all corals identified across sites were also characterized with the Chaol richness and Shannon and Simpson diversity indices using the vegan package (Oksanen 
TABLE 2 | Average coral cover percentage, corals bleaching rates and mortality rates in Coroa Vermelha, Pedra do Silva, and Virada de Fora reefs, Abrolhos Region, Brazil.

\begin{tabular}{|c|c|c|c|c|c|}
\hline & $\begin{array}{c}\text { Relative } \\
\text { abundance } \\
(\%)\end{array}$ & $\begin{array}{l}\text { Healthy } \\
\text { (\%) }\end{array}$ & $\begin{array}{c}\text { Partially } \\
\text { Bleached } \\
(\%)\end{array}$ & $\begin{array}{c}\text { Bleached } \\
(\%)\end{array}$ & $\begin{array}{c}\text { Dead } \\
(\%)\end{array}$ \\
\hline & \multicolumn{5}{|c|}{ Coroa Vermelha } \\
\hline \multicolumn{6}{|l|}{ Coral } \\
\hline Millepora alcicornis & 12.9 & 29.3 & 2.1 & 25.3 & 43.3 \\
\hline Millepora braziliensis & 0.0 & 0.0 & 0.0 & 0.0 & 0.0 \\
\hline Agaricia agaricites & 0.2 & 61.8 & 14.7 & 13.5 & 10.0 \\
\hline Agaricia fragilis & 0.0 & 50.0 & 0.0 & 50.0 & 0.0 \\
\hline Favia gravida & 0.0 & 72.2 & 0.0 & 27.8 & 0.0 \\
\hline Madracis decactis & 0.0 & 0.0 & 0.0 & 0.0 & 0.0 \\
\hline Montastraea cavernosa & 1.8 & 50.0 & 0.0 & 50.0 & 0.0 \\
\hline Mussismilia braziliensis & 0.2 & 66.7 & 5.6 & 27.8 & 0.0 \\
\hline Mussismilia harttii & 0.5 & 44.8 & 1.7 & 45.3 & 8.2 \\
\hline Mussismilia hispida & 2.2 & 54.2 & 6.2 & 38.9 & 0.6 \\
\hline Porites astreoides & 2.8 & 55.8 & 12.7 & 28.9 & 2.6 \\
\hline Siderastrea stellata & 1.4 & 56.2 & 28.1 & 13.3 & 2.3 \\
\hline \multicolumn{6}{|l|}{ Octocorals } \\
\hline Muricea flamma & 0.2 & 100.0 & 0.0 & 0.0 & 0.0 \\
\hline Muriceopsis sulphurea & 1.8 & 89.3 & 3.7 & 4.3 & 2.7 \\
\hline Neospongodes atlantica & 2.0 & 100.0 & 0.0 & 0.0 & 0.0 \\
\hline Phyllogorgia dilatata & 1.1 & 97.5 & 0.0 & 0.0 & 2.5 \\
\hline Plexaurella grandiflora & 0.1 & 75.0 & 25.0 & 0.0 & 0.0 \\
\hline Plexaurella regia & 0.2 & 82.1 & 0.0 & 17.9 & 0.0 \\
\hline \multicolumn{6}{|l|}{ Zoanthids } \\
\hline Palythoa caribaeorum & 3.9 & 53.7 & 19.5 & 26.8 & 0.0 \\
\hline Zoanthus sociatus & 0.0 & 100.0 & 0.0 & 0.0 & 0.0 \\
\hline
\end{tabular}

Pedra Do Silva

\begin{tabular}{|c|c|c|c|c|c|}
\hline \multicolumn{6}{|l|}{ Coral } \\
\hline Millepora alcicornis & 12.0 & 6.0 & 0.8 & 4.1 & 89.1 \\
\hline Millepora braziliensis & 0.0 & 100.0 & 0.0 & 0.0 & 0.0 \\
\hline Agaricia agaricites & 0.2 & 83.5 & 4.0 & 0.0 & 12.5 \\
\hline Agaricia fragilis & 0.0 & 100.0 & 0.0 & 0.0 & 0.0 \\
\hline Favia gravida & 0.1 & 77.8 & 0.0 & 22.2 & 0.0 \\
\hline Madracis decactis & 0.0 & 53.6 & 0.0 & 46.4 & 0.0 \\
\hline Montastraea cavernosa & 0.3 & 100.0 & 0.0 & 0.0 & 0.0 \\
\hline Mussismilia braziliensis & 0.3 & 56.3 & 8.3 & 35.4 & 0.0 \\
\hline Mussismilia harttii & 4.6 & 44.8 & 1.8 & 40.5 & 12.9 \\
\hline Mussismilia hispida & 1.4 & 52.2 & 1.3 & 44.0 & 2.5 \\
\hline Porites astreoides & 0.4 & 82.2 & 9.7 & 2.6 & 5.6 \\
\hline Siderastrea stellata & 2.5 & 57.0 & 17.0 & 25.2 & 0.8 \\
\hline \multicolumn{6}{|l|}{ Octocorals } \\
\hline Muricea flamma & 0.0 & 0.0 & 0.0 & 0.0 & 0.0 \\
\hline Muriceopsis sulphurea & 3.7 & 69.6 & 9.8 & 8.8 & 11.9 \\
\hline Neospongodes atlantica & 3.6 & 88.3 & 0.2 & 4.3 & 7.2 \\
\hline Phyllogorgia dilatata & 0.2 & 85.1 & 3.1 & 10.0 & 1.8 \\
\hline Plexaurella grandiflora & 0.0 & 100.0 & 0.0 & 0.0 & 0.0 \\
\hline Plexaurella regia & 0.0 & 0.0 & 0.0 & 0.0 & 0.0 \\
\hline \multicolumn{6}{|l|}{ Zoanthids } \\
\hline Palythoa caribaeorum & 19.5 & 68.1 & 23.2 & 6.7 & 2.1 \\
\hline Zoanthus sociatus & 0.0 & 100.0 & 0.0 & 0.0 & 0.0 \\
\hline
\end{tabular}

TABLE 2 | Continued

\begin{tabular}{|c|c|c|c|c|c|}
\hline & $\begin{array}{c}\text { Relative } \\
\text { abundance } \\
(\%)\end{array}$ & $\begin{array}{c}\text { Healthy } \\
\text { (\%) }\end{array}$ & $\begin{array}{c}\text { Partially } \\
\text { Bleached } \\
(\%)\end{array}$ & $\begin{array}{c}\text { Bleached } \\
(\%)\end{array}$ & $\begin{array}{c}\text { Dead } \\
(\%)\end{array}$ \\
\hline & \multicolumn{5}{|c|}{ Virada De Fora } \\
\hline \multicolumn{6}{|l|}{ Coral } \\
\hline Millepora alcicornis & 1.1 & 8.4 & 0.0 & 8.1 & 83.5 \\
\hline Millepora braziliensis & 0.0 & 0.0 & 0.0 & 0.0 & 0.0 \\
\hline Agaricia agaricites & 0.1 & 75.0 & 5.0 & 6.7 & 13.3 \\
\hline Agaricia fragilis & 0.0 & 0.0 & 0.0 & 0.0 & 0.0 \\
\hline Favia gravida & 0.1 & 96.4 & 3.6 & 0.0 & 0.0 \\
\hline Madracis decactis & 0.0 & 0.0 & 0.0 & 0.0 & 0.0 \\
\hline Montastraea cavernosa & 0.0 & 0.0 & 0.0 & 0.0 & 0.0 \\
\hline Mussismilia braziliensis & 2.1 & 84.4 & 5.2 & 10.2 & 0.2 \\
\hline Mussismilia harttii & 2.8 & 76.9 & 6.4 & 11.5 & 5.2 \\
\hline Mussismilia hispida & 1.1 & 66.2 & 7.9 & 22.0 & 3.9 \\
\hline Porites astreoides & 0.2 & 56.7 & 16.7 & 26.7 & 0.0 \\
\hline Siderastrea stellata & 14.4 & 50.9 & 15.4 & 33.2 & 0.5 \\
\hline \multicolumn{6}{|l|}{ Octocorals } \\
\hline Muricea flamma & 0.0 & 0.0 & 0.0 & 0.0 & 0.0 \\
\hline Muriceopsis sulphurea & 0.1 & 100.0 & 0.0 & 0.0 & 0.0 \\
\hline Neospongodes atlantica & 0.0 & 0.0 & 0.0 & 0.0 & 0.0 \\
\hline Phyllogorgia dilatata & 0.0 & 0.0 & 0.0 & 0.0 & 0.0 \\
\hline Plexaurella grandiflora & 0.0 & 100.0 & 0.0 & 0.0 & 0.0 \\
\hline Plexaurella regia & 0.0 & 0.0 & 0.0 & 0.0 & 0.0 \\
\hline \multicolumn{6}{|l|}{ Zoanthids } \\
\hline Palythoa caribaeorum & 1.9 & 55.0 & 41.1 & 3.9 & 0.0 \\
\hline Zoanthus sociatus & 0.0 & 100.0 & 0.0 & 0.0 & 0.0 \\
\hline
\end{tabular}

et al., 2019) in the R Statistical Software (R Core Team, 2017). We then used the non-parametric Kruskal-Wallis test to compare these indices among sites.

\section{RESULTS}

\section{Thermal Stress in Abrolhos Bank}

During the 2019 survey period (January to July), there were 9 days with temperatures above $29^{\circ} \mathrm{C}$ and the highest temperature recorded was $29.33^{\circ} \mathrm{C}$ (see text footnote 1 Figure 2). The average temperature through July 2019 was $27.64^{\circ} \mathrm{C}, 1.3^{\circ} \mathrm{C}$ higher than the average temperature for this month from 2010 to $2018\left(26.34^{\circ} \mathrm{C}\right)$. Records were broken with the highest single day temperature documented since 1989 and the highest ever recorded number of DHW in the region (NOAA Abrolhos reef station).

The highest DHW value recorded at the Abrolhos reef station was 19.65, from May 10th, 2019. This almost doubles the historic high of 10.95 DHW, which occurred in 2016 (see text footnote 1 Figure 2). During our survey period, DHW values were above 15 for 50 consecutive days (April 12th-May 31st), and there were 102 total days with DHW values above 10. In contrast, during the period between 2010 and 2018, there were only 61 days with DHW values above 10, and none of these events lasted 


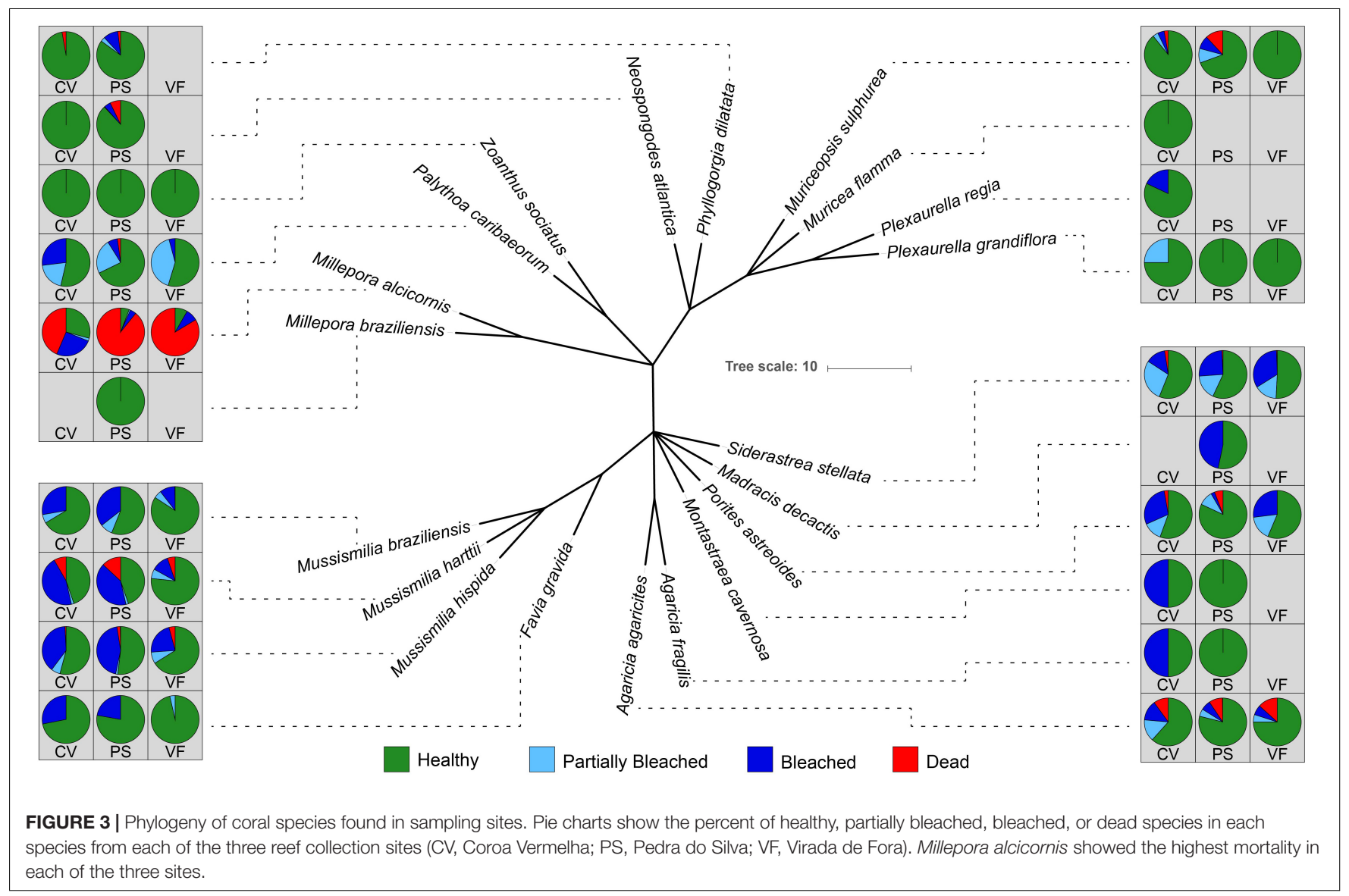

more than 35 consecutive days. The average DHW in 20102018 was $2.77 \pm 0.09$ (average \pm se), whereas during the 2019 survey period it was $10.50 \pm 0.44$ (average \pm se). Historic highs (prior to 2019) peaked at $6.34 \pm 0.31$ (average \pm se), which was recorded from February to July 2016. The average DHW value for 2019 was therefore significantly higher than both the combined averages during heat stress events from 2010 to $2018(p<0.05)$ and the 2016 heat stress event $(p<0.05)$. Using the regional bleaching threshold of $27.9^{\circ} \mathrm{C}^{2}$, there were 114 days recorded above this threshold in 2019 and only 250 such days over the previous 9 years. The mean temperature in $\mathrm{CV}$ and in the IRC are shown in Table 1, as well as other important physical and chemical water parameters.

\section{Relative Abundance, Coral Bleaching Rates and Mortality Rates}

Benthic cover by species, coral bleaching rates, and mortality rates for all coral species observed was calculated for the three sampling sites (Table 2). In the two sampling sites in the IRC, the mortality rate for the hydrocoral Millepora alcicornis averaged $\sim 86 \%$, (going up to almost $90 \%$ in VF) while in Coroa Vermelha the reef mortality rate was $\sim 43 \%$ (Figure 3 ). In the three sampling sites, the species belonging to the Mussismilia genus

${ }^{2}$ https://coralreefwatch.noaa.gov presented bleaching rates between 10 and $45 \%$, but mortality rates between 0 and $12.9 \%$. Of the three Mussusmilia species, M. hartii had the highest mortality rates in all reefs.

\section{Major Groups Total Cover and Total Coral Mortality}

Of the three reefs analyzed, total live coral cover was $9.7 \pm 2.3 \%$ in CV Reefs, $8.5 \pm 2.0 \%$ in PS, and $14.5 \pm 0.9 \%$ in VF (Table 3). Although CV and PS reefs presented a higher coral cover before the heat event, VF reef currently presents a higher coral cover $(14.5 \pm 2.9 \%)$ while having a lower mortality $(1.2 \pm 0.5 \%)$. Recently dead corals represent a majority of the dead corals that were found in the region. In CV, RDC represent $9.1 \pm 3.6 \%$, the same coverage percent of the live corals. In PS, the percent of $\operatorname{RDC}(15.5 \pm 3.2 \%)$ is almost twice the percent of live corals $(8.5 \pm 2.0 \%)$ (Table 3$)$.

\section{DISCUSSION}

Here we report a high mortality rate for the hydrocoral species Millepora alcicornis, and the first event on record of heat-related massive coral mortality in the western South Atlantic. This record breaking mortality was recorded during the 2019 heatwave event. M. alcicornis is a branching hydrocoral and one of the major reef 
TABLE 3 | Benthic cover by major groups and total coral mortality rates in Coroa Vermelha, Pedra do Silva, and Virada de Fora reefs (se = standard error).

\begin{tabular}{|c|c|c|c|c|c|c|}
\hline & \multicolumn{2}{|c|}{ Coroa Vermelha } & \multicolumn{2}{|c|}{ Pedra do Silva } & \multicolumn{2}{|c|}{ Virada de Fora } \\
\hline & pct_mean & pct_se & pct_mean & pct_se & pct_mean & pct_se \\
\hline Live Coral & 9.7 & 2.3 & 8.5 & 2.0 & 14.5 & 0.9 \\
\hline Recently Dead Coral & 9.1 & 3.6 & 15.6 & 3.2 & 1.2 & 0.5 \\
\hline Old Dead Coral & 0.3 & 0.1 & 4.9 & 0.8 & 0.3 & 0.1 \\
\hline Octocorals & 6.3 & 3.0 & 7.6 & 2.0 & 0.2 & 0.1 \\
\hline Zoanthids & 2.6 & 1.9 & 16.8 & 3.6 & 1.2 & 1.0 \\
\hline Macroalgae & 32.8 & 6.0 & 13.0 & 1.8 & 67.5 & 3.3 \\
\hline Coralline Algae & 23.7 & 4.7 & 3.8 & 0.8 & 1.5 & 0.8 \\
\hline Sponges & 0.1 & 0.0 & 0.5 & 0.1 & 0.0 & 0.0 \\
\hline Others & 0.4 & 0.1 & 0.2 & 0.1 & 0.3 & 0.1 \\
\hline Unknowns & 0.6 & 0.2 & 0.3 & 0.1 & 0.5 & 0.2 \\
\hline Sand, Pavement, Rubble & 14.4 & 3.0 & 29.0 & 3.2 & 13.0 & 3.3 \\
\hline
\end{tabular}

builders in the area (Amaral et al., 2008). The species occupies the windward borders of the majority of reefs in this region, in a similar manner to the habitat where Acropora palmata dominated in Caribbean reefs (Leão et al., 2003). Although M. alcicornis has shown a sensitivity to bleaching, low mortality rates have been previously observed in Brazil (<8\%) (Miranda et al., 2013; Teixeira et al., 2019). In contrast, here we observed (across two independent sampling sites in the IRC), a staggering increase in mortality of this reef builder - with highs of $\sim 84$ and $89 \%$ in Virada de Fora and Pedra do Silva, respectively, and $~ 43 \%$ in Coroa Vermelha.

The 2019 bleaching event therefore became the most detrimental thermal stress event since records began, not only on the reefs surveyed but throughout the western South Atlantic. DHWs peaked in this location at a high of 19.65, a record for the Abrolhos region, and the second highest value ever documented in the western South Atlantic. This peak has only been surpassed once before where 20.5 DHW were recorded in Alcatrazes, off the São Paulo coast (Banha et al., 2019). Interestingly, although the stress event was higher during the episode in Alcatrazes (higher DHW value) and, despite $70 \%$ of the corals bleaching, mortality was low $(<2 \%)$ (Banha et al., 2019). At the same site as our surveys, 70\% of corals bleached during a 2016 thermal stress event (with DHW peak at only 9.7), however, less than $3 \%$ of total coral cover was lost (Teixeira et al., 2019). Although we recognize that the use of local temperature loggers would be the most recommended approach, for us to compare all the studied areas with higher resolution, satellite-derived SST surveys have been extensively applied as a reliable alternative (Donner et al., 2005; Skirving et al., 2019; Teixeira et al., 2019).

The significant die off observed is worrying for the entire ecosystem, as Millepora alcicornis is a major reef builder of Brazilian reefs and they provide an important nursery habitat for a number of reef species (Coni et al., 2013). Although M. alcicornis has a relatively fast growth rate (when compared with other coral species), extending approximately $2.4 \mathrm{~cm} /$ year (Oliveira et al., 2008), due to the size of the dead colonies, we believe that reef recovery will take decades. The knock on effect of such an event may therefore result in not only loss of biodiversity, but local extinctions of other reef taxa and declines in fisheries productivity (Rogers et al., 2014). This die off also raises concerns about the status of this reef as a refuge. The previous absence of significant mortality of corals in this area may not actually indicate a higher resilience or resistance, instead, such observations may have been solely due to the lack of major heatwaves in the past. In fact, comparing the temperature history of different areas, heat stress in the Southern Atlantic has been historically lower than in other oceans (Skirving et al., 2019). It is also possible that corals living in these areas have simply not yet reached their threshold because light stress is lower in this region due to turbidity. However, in accentuated heatwave events like in 2019, these corals might be as sensitive as other species on other reefs. Indeed, it was demonstrated that Mussismilia harttii colonies from the same region bleached when exposed to increased water temperature $\left(2.0\right.$ and $4.5^{\circ} \mathrm{C}$ above the ambient temperature) (Santos et al., 2014).

Despite the increased mortality observed in 2019, there is a glimmer of hope associated with such devastation. First, we still need to follow up and monitor the natural recovery of the affected coral groups. Besides, one promising approach for the recovery of damaged reefs is the use of active coral restoration. In this context, it is important to also look at the survival rate during major heatwave events. In the case of $M$. alcicornis restoration, despite the overall high number of dead corals, a few colonies did not die or suffer, due to the intense heat stress. These resistant colonies may be the key to understanding and preserving corals in this area. Individual coral colonies from the same species are well known to react differently to stress (Hughes et al., 2017) with survivors appearing resilient and/or acclimated to heat stress (Supplementary Figure S1). These thermo-tolerant colonies, or colonies that bleach and recover (i.e., resilient), can be studied and used as donors for coral restoration strategies in the field (Oliveira et al., 2008; Calderon et al., 2015), as part of mitigatory actions. However, even naturally heat-resistant corals are significantly threatened by periods of sustained heatwaves (Le Nohaïc et al., 2017) and the only permanent solution is the reduction of $\mathrm{CO}_{2}$ emissions. 
Unlike the $M$. alcicornis mortality rates, all the other species of hydrocorals, corals, octocorals, and zoanthids showed low mortality rates (Table $\mathbf{1}$ and Figure 3 ). This event also led to the highest mortality rate ever reported for the genus Mussusmilia due to a heatwave event in the South Atlantic. Previous mortality rates for M. hispida varied between 0.5 and $3.9 \%$. These results show that, although some reef builders from the WSA are susceptible to bleaching, some may also be resilient and recover from the heat stress. These thermotolerant corals could become important genetic stocks in the near future and should be urgently and continuously monitored. The microbiome associated with local coral species, especially when comparing thermal resistant and sensitive colonies, should also be investigated further for the potential development of coral probiotics (Peixoto et al., 2017; Rosado et al., 2019). However, it is also important to highlight that although the total mortality was low in some species, the most important reef-building hydrocorals had the highest mortality. Also, the highest ever recorded rates of mortality for other coral species were observed and are consistent with higher DHW in this region.

Finally, we highlight that following this documented massbleaching event, the same reefs surveyed were hit by an oil spill, of which impacts are still unknown (Escobar, 2019). Therefore, considering the high mortality and sensitivity of $M$. alcicornis to the 2019 bleaching event, and secondary threats that may impact and threaten Brazilian reefs, we suggest that the species is added to the Brazilian list of endangered species. Interestingly, M. alcicornis was already listed as "endangered" in the Ministry of the Environment Ordinance No. 005 (MMA, 2004), but lost the status in 2014 (MMA, 2014). and was downgraded to "Least Concern." Together with the evaluation of restoration projects (Oliveira et al., 2008; Calderon et al., 2015), we suggest the implementation of policies that lead to the decline in carbon emissions, stricter environmental rules, and extra monitoring of potential environment-damaging activities in the region, as well as to monitor and evaluate the natural recovery of these reefs.

\section{REFERENCES}

Amaral, F., Steiner, A., Broadhurst, M., and Cairns, S. (2008). An overview of the shallow-water calcified hydroids from Brazil (Hydrozoa: Cnidaria), Including the description of a new species. Zootaxa 1930, 56-68. doi: 10.5281/zenodo. 184834

Anthony, K. R. N., and Fabricius, K. E. (2000). Shifting roles of heterotrophy and autotrophy in coral energetics under varying turbidity. J. Exp. Mar. Biol. Ecol. 252, 221-253. doi: 10.1016/s0022-0981(00)00237-9

Banha, T. N. S., Capel, K. C. C., Kitahara, M. V., Francini-Filho, R. B., Francini, C. L. B., Sumida, P. Y. G., et al. (2019). Low coral mortality during the most intense bleaching event ever recorded in subtropical Southwestern Atlantic reefs. Coral Reefs. doi: 10.1007/s00338-019-01856-y

Burke, L., Reytar, K., Spalding, M. D., and Perry, A. (2011). Reefs at RISK REVISited. Washington, DC: World Resources Institute. doi: 10.1016/00220981(79)90136-9

Cacciapaglia, C., and van Woesik, R. (2015). Reef-coral refugia in a rapidly changing ocean. Glob. Chang. Biol. 21, 2272-2282. doi: 10.1111/gcb.12851

Calderon, E. N., Zilberberg, C., and Castro, C. B. E. (2015). Farming of the fire-coral $\mathrm{M}$ illepora alcicornis for reef restoration purposes: the influence of inclination on growth. Aquac. Res. 46, 2034-2036. doi: 10.1111/are. 12338

\section{DATA AVAILABILITY STATEMENT}

The images generated from the video transects used for the survey are available in the Zenodo data bank (doi: 10.5281/zenodo. 3713345).

\section{AUTHOR CONTRIBUTIONS}

GD, RP, HV, and MS: study conception and design. GD and MD: conducting field work. All authors: analyses and data interpretation and involved in critical revision. HV, RP, and GD: drafting of the manuscript. RP and MS: provided financial support.

\section{ACKNOWLEDGMENTS}

We would like to thank Dande Deocleciano, Pinho Deocleciano, and Valdeir Bonfim for their support during field work. Without all the support of the local community of Corumbau, Brazil, this work would not be possible. We would also like thank the Graduate Programs of Science (Microbiology) and Vegetal Biotechnology and Bioprocess Engineering (PBV)/Federal University of Rio de Janeiro, the National Council for Scientific and Technological Development (CNPq), the National Council for the Improvement of Higher Education (CAPES), and the Rio de Janeiro Marine Aquarium (AquaRio) research center for their support.

\section{SUPPLEMENTARY MATERIAL}

The Supplementary Material for this article can be found online at: https://www.frontiersin.org/articles/10.3389/fmars. 2020.00179/full\#supplementary-material

Coni, E. O. C., Ferreira, C. M., de Moura, R. L., Meirelles, P. M., Kaufman, L., and Francini-Filho, R. B. (2013). An evaluation of the use of branching fire-corals (Millepora spp.) as refuge by reef fish in the Abrolhos Bank, eastern Brazil. Environ. Biol. Fishes 96, 45-55. doi: 10.1007/s10641-012-0021-6

Costa, O. S. Jr. (2007). Anthropogenic nutrient pollution of coral reefs in Southern Bahia, Brazil. Braz. J. Oceanogr. 55, 265-279. doi: 10.1590/S167987592007000400004

Côté, I. M., and Darling, E. S. (2010). Rethinking ecosystem resilience in the face of climate change. PLoS Biol. 8:e1000438. doi: 10.1371/journal.pbio.1000438

De'ath, G., Fabricius, K. E., Sweatman, H., and Puotinen, M. (2012). The 27-year decline of coral cover on the Great Barrier Reef and its causes. Proc. Natl. Acad. Sci. U.S.A. 109, 17995-17999. doi: 10.1073/pnas.1208909109

Donner, S. D., Skirving, W. J., Little, C. M., Oppenheimer, M., and Hoegh-Gulberg, O. (2005). Global assessment of coral bleaching and required rates of adaptation under climate change. Glob. Chang. Biol. 11, 2251-2265. doi: 10.1111/j.13652486.2005.01073.x

Escobar, H. (2019). Mystery oil spill threatens marine sanctuary in Brazil. Science 366:672. doi: $10.1126 /$ science.366.6466.672

Guest, J. R., Edmunds, P. J., Gates, R. D., Kuffner, I. B., Andersson, A. J., Barnes, B. B., et al. (2018). A framework for identifying and characterising coral reef "oases" against a backdrop of degradation. J. Appl. Ecol. 55, 2865-2875. doi: $10.1111 / 1365-2664.13179$ 
Hill, J., and Wilkinson, C. (2004). Methods for Ecological Monitoring of Coral Reefs. Townsville: Australian Institute of Marine Science.

Hughes, T. P., Anderson, K. D., Connolly, S. R., Heron, S. F., Kerry, J. T., Lough, J. M., et al. (2018). Spatial and temporal patterns of mass bleaching of corals in the Anthropocene. Science 359, 80-83. doi: 10.1126/science.aan8048

Hughes, T. P., Kerry, J. T., Álvarez-Noriega, M., Álvarez-Romero, J. G., Anderson, K. D., Baird, A. H., et al. (2017). Global warming and recurrent mass bleaching of corals. Nature 543, 373-377. doi: 10.1038/nature21707

Kayanne, H. (2017). Validation of degree heating weeks as a coral bleaching index in the northwestern Pacific. Coral Reefs 36, 63-70. doi: 10.1007/s00338-016$1524-y$

Kohler, K. E., and Gill, S. M. (2006). Coral Point Count with Excel extensions (CPCe): a Visual Basic program for the determination of coral and substrate coverage using random point count methodology. Comput. Geosci. 32, 12591269. doi: 10.1016/j.cageo.2005.11.009

Le Nohaï, M., Ross, C. L., Cornwall, C. E., Comeau, S., Lowe, R., McCulloch, M. T., et al. (2017). Marine heatwave causes unprecedented regional mass bleaching of thermally resistant corals in northwestern Australia. Sci. Rep. 7:14999. doi: 10.1038/s41598-017-14794-y

Leão, Z. M. D. A. N., Kikuchi, R. K. P., and Oliveira, M. D. M. (2008). Branqueamento de corais nos recifes da Bahia e sua relação com eventos de anomalias térmicas nas águas superficiais do oceano. Biota Neotrop. 8, 069-082. doi: $10.1590 /$ S1676-06032008000300006

Leão, Z. M. D. A. N., Kikuchi, R. K. P., and Testa, V. (2003). "Corals and coral reefs of Brazil," in Latin American Coral Reefs, ed. J. Cortés (Amsterdam: Elsevier), 9-52. doi: 10.1016/B978-044451388-5/50003-5

Miranda, R. J., Cruz, I. C. S., and Leão, Z. (2013). Coral bleaching in the Caramuanas reef (Todos os Santos Bay, Brazil) during the 2010 El Niño event. Lat. Am. Aquat. Res. 41, 351-360. doi: 10.3856/vol41-issue2-fulltext- 14

MMA (2004). Instrução Normativa $n^{\circ}$ 5, de 21 de maio de 2004. Brasília: Consulex. MMA (2014). Portaria $n^{\circ}$ 445, de 17 de dezembro de 2014. Brasília: Consulex.

Morgan, K. M., Perry, C. T., Johnson, J. A., and Smithers, S. G. (2017). Nearshore turbid-zone corals exhibit high bleaching tolerance on the Great Barrier Reef following the 2016 ocean warming event. Front. Mar. Sci. 4:224. doi: 10.3389/ fmars.2017.00224

Morgan, K. M., Perry, C. T., Smithers, S. G., Johnson, J. A., and Daniell, J. J. (2016). Evidence of extensive reef development and high coral cover in nearshore environments: implications for understanding coral adaptation in turbid settings. Sci. Rep. 6:29616. doi: 10.1038/srep29616

National Academies of Sciences and Medicine (2019). A Research Review of Interventions to Increase the Persistence and Resilience of Coral Reefs. Washington, DC: The National Academies Press, doi: 10.17226/25279

Ogle, D. H., Wheeler, P., and Dinno, A. (2019). FSA: Fisheries Stock Analysis. $R$ package version 0.8.25. Available online at: https://github.com/droglenc/FSA (accessed November 25, 2019).

Oksanen, J., Blanchet, G., Friendly, M., Kindt, R., Legendre, P., McGlinn, D., et al. (2019). Vegan: Community Ecology Package (R Package Version 2.5-5). Available online at: https://CRAN.R-project.org/package=vegan (accessed November 25, 2019).
Oliveira, M. D. M., Kikuchi, R. K. P., and Leão, Z. M. D. A. N. (2008). Cultivo de Millepora alcicornis como uma ferramenta para Restauração e Manejo dos Ecossistemas Recifais do. Nord. Brasil. 8, 183-201. doi: 10.5894/rgci148

Paulay, C. (1997). Life and Death of Coral Reefs. New York, NY: Chapman and Hall, 298-353.

Peixoto, R., Rosado, P. M., Leite, D. C., de, A., Rosado, A. S., and Bourne, D. G. (2017). Beneficial Microorganisms for Corals (BMC): proposed Mechanisms for Coral Health and Resilience. Front. Microbiol. 8:341. doi: 10.3389/fmicb.2017. 00341

Perry, C. T., Murphy, G. N., Kench, P. S., Smithers, S. G., Edinger, E. N., Steneck, R. S., et al. (2013). Caribbean-wide decline in carbonate production threatens coral reef growth. Nat. Commun. 4:1402. doi: 10.1038/ncomms 2409

R Core Team (2017). R: A Language and Environment for Statistical Computing. Vienna: R Foundation for Statistical Computing. Available online at: https: //www.R-project.org (accessed November 25, 2019).

Rogers, A., Blanchard, J. L., and Mumby, P. J. (2014). Vulnerability of coral reef fisheries to a loss of structural complexity. Curr. Biol. 24, 1000-1005. doi: 10.1016/j.cub.2014.03.026

Rosado, P., Leite, D. C. A., Duarte, G. A. S., Chaloub, R. M., Jospin, G., Nunes da Rocha, U., et al. (2019). Marine probiotics: increasing coral resistance to bleaching through microbiome manipulation. ISME J. 13, 921-936. doi: 10. 1038/s41396-018-0323-6

Santos, H., Carmo, F. L., Duarte, G., Dini-Andreote, F., Castro, C. B., Rosado, A. S., et al. (2014). Climate change affects key nitrogen-fixing bacterial populations on coral reefs. ISME J. 8:2272. doi: 10.1038/ismej. 2014.70

Skirving, W. J., Heron, S. F., Marsh, B. L., Liu, G., De La Cour, J. L., Geiger, E. F., et al. (2019). The relentless march of mass coral bleaching: a global perspective of changing heat stress. Coral Reefs 38, 547-557. doi: 10.1007/s00338-01901799-4

Teixeira, C. D., Leitão, R. L. L., Ribeiro, F. V., Moraes, F. C., Neves, L. M., Bastos, A. C., et al. (2019). Sustained mass coral bleaching (2016-2017) in Brazilian turbid-zone reefs: taxonomic, cross-shelf and habitat-related trends. Coral Reefs 38, 801-813. doi: 10.1007/s00338-019-01 789-6

Conflict of Interest: The authors declare that the research was conducted in the absence of any commercial or financial relationships that could be construed as a potential conflict of interest.

Copyright (c) 2020 Duarte, Villela, Deocleciano, Silva, Barno, Cardoso, Vilela, Rosado, Messias, Chacon, Santoro, Olmedo, Szpilman, Rocha, Sweet and Peixoto. This is an open-access article distributed under the terms of the Creative Commons Attribution License (CC BY). The use, distribution or reproduction in other forums is permitted, provided the original author(s) and the copyright owner(s) are credited and that the original publication in this journal is cited, in accordance with accepted academic practice. No use, distribution or reproduction is permitted which does not comply with these terms. 